\title{
Kinetics of ferrous iron oxidation by Sulfobacillus thermosulfidooxidans
}

\author{
Pablo S. Pina ${ }^{1}$, Victor A. Oliveira, Flávio L.S. Cruz, Versiane A. Leão* \\ Universidade Federal de Ouro Preto, Department of Metallurgical and Materials Engineering, Bio\&Hidrometallurgy Laboratory, Campus Morro do Cruzeiro, \\ s.n., Ouro Preto, MG 35400-000, Brazil
}

\section{A R T I C L E I N F O}

\section{Article history:}

Received 9 October 2009

Received in revised form 1 June 2010

Accepted 10 June 2010

\section{Keywords:}

Growth kinetics

Thermophiles

Batch processing

Microbial growth

Waste treatment

\begin{abstract}
A B S T R A C T
The biological oxidation of ferrous iron is an important sub-process in the bioleaching of metal sulfides and other bioprocesses such as the removal of $\mathrm{H}_{2} \mathrm{~S}$ from gases, the desulfurization of coal and the treatment of acid mine drainage (AMD). As a consequence, many Fe(II) oxidation kinetics studies have mostly been carried out with mesophilic microorganisms, but only a few with moderately thermophilic microorganisms. In this work, the ferrous iron oxidation kinetics in the presence of Sulfobacillus thermosulfidooxidans (DSMZ 9293) was studied. The experiments were carried out in batch mode (2L STR) and the effect of the initial ferrous iron concentration $\left(2-20 \mathrm{~g} \mathrm{~L}^{-1}\right)$ on both the substrate consumption and bacterial growth rate was assessed. The Monod equation was applied to describe the growth kinetics of this microorganism and values of $\mu_{\max }$ and $K_{\mathrm{s}}$ of $0.242 \mathrm{~h}^{-1}$ and $0.396 \mathrm{~g} \mathrm{~L}^{-1}$, respectively, were achieved. Due to the higher temperature oxidation, potential benefits on leaching kinetics are forecasted.
\end{abstract}

(C) 2010 Elsevier B.V. All rights reserved.

\section{Introduction}

Bioleaching is now a proven technology that has been applied to the processing of a series of metallic sulfides such as copper, uranium and refractory gold ores. Two mechanisms have been proposed to explain the bacterial attack on the sulfides: (i) the direct mechanism, which relies on the catalytic oxidation of the metallic sulfide. This mechanism is thought to be important whenever there is a direct contact between the bacteria and the mineral, as for example, in heap bioleaching. The second mechanism refers to the biological production of $\mathrm{Fe}(\mathrm{III})$ and its role on the oxidation of sulfides [1] which follows different patterns according to sulfide electronic configuration. Some are oxidized directly to sulfate while others are oxidized to elemental sulfur. Notwithstanding, ferrous iron is a by-product and needs to be biologically re-oxidized by the bacteria.

Owing to the numerous potential applications of ferrous iron bio-oxidation, several works were carried out with mesophilic microorganisms, especially with Acidithiobacillus ferrooxidans and Leptospirillum ferrooxidans [2], and a number of kinetic models have been proposed for the oxidation of ferrous iron [3,4] in the temperature range usually found in industrial applications. Nemati et al. [3] compared the batch kinetics of Fe(II) oxidation by A. ferrooxidans and Acidianus brierleyi, at $\mathrm{pH} 1.8$. The authors observed that the

\footnotetext{
* Corresponding author. Tel.: +55 313559 1102; fax: +55 3135591596.

E-mail addresses: versiane@demet.em.ufop.br, va.leao@uol.com.br (V.A. Leão). 1 Current address: Vale - Centro de Desenvolvimento Mineral, Santa Luzia, Minas Gerais, Brazil.
}

mesophile microorganism was able to grow in the presence of up to $30 \mathrm{~g} \mathrm{~L}^{-1} \mathrm{Fe}(\mathrm{II})$, but the maximum oxidation rate $\left(0.47 \mathrm{~g} \mathrm{~L}^{-1} \mathrm{~h}^{-1}\right)$ was observed only in the presence of $20 \mathrm{~g} \mathrm{~L}^{-1} \mathrm{Fe}(\mathrm{II})$. The thermophiles were more sensible to the presence of Fe(II) and did not grow at concentrations higher than $5.8 \mathrm{~g} \mathrm{~L}^{-1} \mathrm{Fe}(\mathrm{II})$. In this substrate concentration, an overall oxidation rate of $0.105 \mathrm{~g} \mathrm{~L}^{-1} \mathrm{~h}^{-1}$ was achieved. The authors also determined the specific growth rate $(\mu)$ and the yield $(Y)$ for $A$. brierleyi as $0.028 \mathrm{~h}^{-1}$ and $1.9 \times 10^{10}$ cells $^{-1}$, respectively.

Moderate thermophiles have shown the ability to improve bioleaching kinetics of selected sulfides due to the higher bioleaching temperature as compared to mesophiles. As the indirect mechanism plays a key role in most bioleaching systems and only few ferrous iron bio-oxidation kinetics studies were performed with moderately thermophilic microorganisms, this work aimed to address Fe(II) oxidation with Sulfobacillus thermosulfidooxidans.

\section{Materials and methods}

S. thermosulfidooxidans (strain DSMZ 9293) was grown in a medium containing: $0.4 \mathrm{~g} \mathrm{~L}^{-1}\left(\mathrm{NH}_{4}\right)_{2} \mathrm{SO}_{4}, 0.8 \mathrm{gL}^{-1} \mathrm{MgSO}_{4} \cdot 7 \mathrm{H}_{2} \mathrm{O}$, $0.4 \mathrm{~g} \mathrm{~L}^{-1} \mathrm{~K}_{2} \mathrm{HPO}_{4}, 10 \mathrm{~g} \mathrm{~L}^{-1}$ of ferrous iron and $0.1 \mathrm{~g} \mathrm{~L}^{-1}$ yeast extract and provided the inoculum for the bio-oxidation experiments from a $48 \mathrm{~h}$ grown culture.

The bio-oxidation experiments were carried out in batch mode in a bioreactor (New Brunswick Scientific - BioFlo 110) with $2 \mathrm{~L}$ of suspension containing $10 \%$ (volume) of inoculum. To produce the latter, $400 \mathrm{~mL}$ of the culture were filtered through a Millipore $(0.22 \mu \mathrm{m})$ membrane and resuspended in $200 \mathrm{~mL}$ of distilled water, at $\mathrm{pH}$ 2.0. Afterwards the $\mathrm{pH}$ was reduced to 1.5 and kept at this 


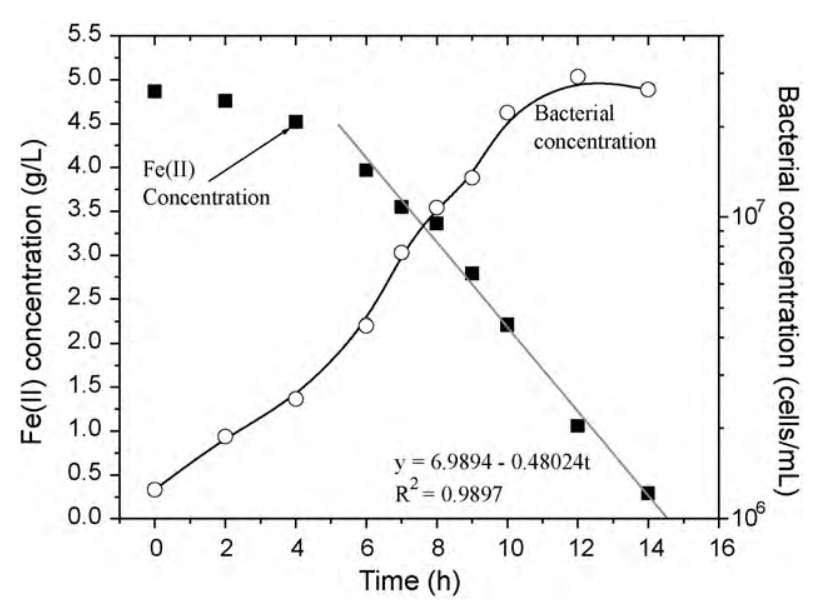

Fig. 1. Ferrous ion concentrations and cell numbers as a function of time for the growth of $S$. thermosulfidooxidans. $[\mathrm{Fe}(\mathrm{II})]_{0}=5 \mathrm{~g} \mathrm{~L}^{-1} ; 50^{\circ} \mathrm{C}, 10 \%$ inoculum, $\mathrm{pH} 1.5$.

value in all experiments. A pH meter (Hanna 2221) and glass membrane electrode calibrated against $\mathrm{pH} 4.0$ and 7.0 buffers was used for $\mathrm{pH}$ measurement. The $\mathrm{pH}$ was controlled during the experiments by addition of either concentrate sulfuric acid or sodium hydroxide. Both the temperature and the stirring rate were maintained constant at $50^{\circ} \mathrm{C}$ and $31.43 \mathrm{rad} \mathrm{s}^{-1}$, respectively. This latter was defined as the value which produced the highest ferrous iron oxidation rate. The initial ferrous iron concentration varied from 2 to $20 \mathrm{~g} \mathrm{~L}^{-1}$. The solution was aerated at a rate of $1 \mathrm{~L} \mathrm{~min}^{-1}$ and $5 \mathrm{~mL}$ samples were withdrawn regularly and analyzed for ferrous iron concentration and cell number. Cell counts were performed using a Neubauer chamber and light contrast microscope (Leica).

The ferrous iron concentration was determined by titration with standard potassium dichromate solution in the presence of a $1 \mathrm{H}_{2} \mathrm{SO}_{4}: 1 \quad \mathrm{H}_{3} \mathrm{PO}_{4}$ solution using an automatic titrator (Schott-Tritoline Alpha). All chemicals used in this study were analytical grade reagents (AR) unless otherwise stated and all solutions were prepared with distilled water.

Statistical analysis was carried out using the Origin $^{\mathrm{TM}}$ version 8.0 software to determine the specific growth rate, the Fe(II) oxidation rate as well as the yield values for a $95 \%$ confidence interval. The data points used to calculate such parameters were those that produced linear regression with correlation coefficients $\left(r^{2}\right)$ higher than 0.94 .

\section{Results and discussion}

The biological oxidation of ferrous iron has been extensively studied in the presence of mesophilic microorganisms (growth temperature between 30 and $40^{\circ} \mathrm{C}$ ), conventionally, A. ferrooxidans and $L$. ferrooxidans [1-4]. Nevertheless, the literature presents few works performed with moderately thermophilic and thermophilic microorganisms $[5,6]$ contrasting with the recent interest in the application of high and moderate temperatures in the bioleaching of metal sulfides [7].

Fig. 1 presents a typical variation on both ferrous ion concentration and bacterial counts during the $\mathrm{Fe}(\mathrm{II})$ bio-oxidation with $S$. thermosulfidooxidans. The increase in the microbial population is coupled to the decrease in the substrate concentration (Fe(II)), as expected. This decrease in substrate concentration with time for different initial Fe(II) concentrations is presented in Fig. 2 and is consistent with studies on $\mathrm{Fe}(\mathrm{II})$ oxidation with $A$. ferrooxidans [5].

As shown in Fig. 1, the ferrous iron consumption rate $d F e(I I) / d t$, which is equivalent in absolute terms to the $\mathrm{Fe}(\mathrm{II})$ oxidation rate, was taken as the slope of the linear part of the profile of ferrous iron concentration versus time [6]. Similarly, the bacterial growth rate $d X / d t$ was calculated according to Eqs. (1) and (2), where $\mu$ is the specific growth rate.

$$
\begin{aligned}
& \mu=\frac{1}{X} \frac{d X}{d t} \\
& \left(\frac{d X}{d t}\right)=\mu X \quad \text { or } \quad \operatorname{Ln}\left(\frac{X}{X_{0}}\right)=\mu t
\end{aligned}
$$

Eq. (2) represents exponential growth and applies to closed systems where growth is the only process affecting cell concentration $(X)$ [7]. A plot of $\operatorname{Ln} X$ versus time gives a straight line with slope $\mu$.

Following, a set of specific growth rate values at different initial ferrous iron concentration was achieved and the experimental data were then fit to the Monod equation so that the maximum specific growth rate $\left(\mu_{\max }\right)$ and the substrate constant $\left(K_{\mathrm{s}}\right)$ could be assessed. The Monod equation is the most widely used expression to correlate the growth of bioleaching microorganisms with ferrous iron concentration and does not consider inhibitory effects in its standard form [8]. In batch systems, it applies only for balanced growth, which is most cultures, occurs concurrently with the exponential growth phase [7].

Fig. 3 shows the ferrous iron oxidation rate and the microbial specific growth rate as a function of the initial ferrous iron concentration. A maximum overall oxidation rate of $0.697 \mathrm{~g} \mathrm{~L}^{-1} \mathrm{~h}^{-1}$ was observed in the experiments carried out with $10 \mathrm{~g} \mathrm{~L}^{-1} \mathrm{Fe}(\mathrm{II})$ and did not change for higher concentrations (15 and $20 \mathrm{~g} \mathrm{~L}^{-1}$ ) (Fig. 3a). The value achieved for $S$. thermosulfidooxidans is 5 times higher than that determined by Nemati and Harrison [6] in experiments carried out with $A$. brierleyi $\left(0.133 \mathrm{~g} \mathrm{~L}^{-1} \mathrm{~h}^{-1}\right.$, in systems containing $7.5 \mathrm{~g} \mathrm{~L}^{-1}$ $\mathrm{Fe}(\mathrm{II}))$ and higher than the value reported by the same authors for A. ferrooxidans $\left(0.47 \mathrm{~g} \mathrm{~L}^{-1} \mathrm{~h}^{-1}\right)$, at $20 \mathrm{~g} \mathrm{~L}^{-1} \mathrm{Fe}(\mathrm{II})$.

The bacterial specific growth rate shows similar behavior leveling out at around $0.25 \mathrm{~h}^{-1}$ for the $10-20 \mathrm{~g} \mathrm{~L}^{-1} \mathrm{Fe}(\mathrm{II})$ concentration range (Fig. 3b). This value is similar to that $\left(0.35 \mathrm{~h}^{-1}\right)$ achieved by Bogdanova et al. [9] in the presence of $9.82 \mathrm{~g} \mathrm{~L}^{-1} \mathrm{FeSO}_{4} \cdot 7 \mathrm{H}_{2} \mathrm{O}$, for a new species of Sulfobacillus with an optimum growth temperature of $40^{\circ} \mathrm{C}$. Applying the Monod equation to the data here presented (Fig. 3b), ferrous iron bio-oxidation can be described by the parameters $\mu_{\max }$ and $K_{\mathrm{s}}$ as $0.242 \mathrm{~h}^{-1}$ and $0.396 \mathrm{~g} \mathrm{~L}^{-1}$, respectively. Nemati et al. [3] after compiling $\mu_{\max }$ and $K_{\mathrm{s}}$ data available in the literature for the growth of Acidithiobacillus ferooxidans pointed out significant discrepancies in the reported values. Notwithstanding, the values observed in the present work are generally higher than those presented by the authors. Similarly, Gomés and Cantero [10] reported $\mu_{\max }$ and $K_{\mathrm{s}}$ as $0.14 \mathrm{~h}^{-1}$ and $0.94 \mathrm{~g} \mathrm{~L}^{-1}$ at $\mathrm{pH} 2.0$ while Liu et al. [11] observed $\mu_{\max }=0.11 \mathrm{~h}^{-1}$, for $A$. ferrooxidans, at $35^{\circ} \mathrm{C}$ and

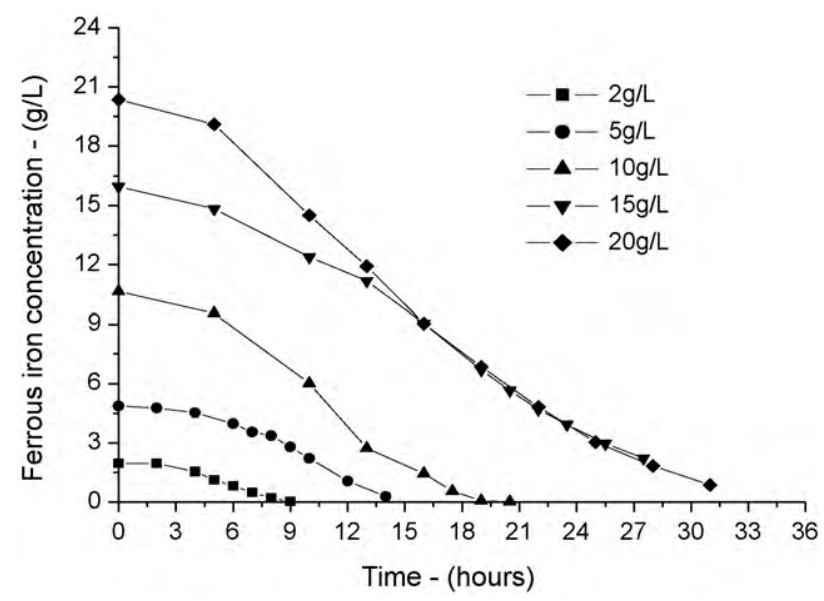

Fig. 2. Variation of the ferrous iron concentration with time during the growth of $S$. thermosulfidooxidans. $50{ }^{\circ} \mathrm{C}, 10 \%$ inoculum, $\mathrm{pH} 1.5$. 
Table 1

Ferrous iron oxidation rate, specific growth rate and yield determined for Sulfobacillus thermosulfidooxidans.

\begin{tabular}{|c|c|c|c|c|c|}
\hline$[\mathrm{Fe}(\mathrm{II})]_{\text {initial }}\left(\mathrm{g} \mathrm{L}^{-1}\right)$ & Specific growth rate $\left(\mathrm{h}^{-1}\right)$ & Bio-oxidation rate $\left(\mathrm{g} \mathrm{L}^{-1} \mathrm{~h}^{-1}\right)$ & Yield $\left(10^{9}\right.$ cells $\left.\mathrm{g}^{-1}\right)$ & Bacteria & Reference \\
\hline 2 & $0.197 \pm 0.012$ & $0.292 \pm 0.034$ & $4.177 \pm 0.960$ & Sulfobacillus & This work \\
\hline 5 & $0.220 \pm 0.025$ & $0.480 \pm 0.056$ & $7.616 \pm 1.197$ & Sulfobacillus & This work \\
\hline 10 & $0.248 \pm 0.096$ & $0.697 \pm 0.140$ & $4.206 \pm 0.522$ & Sulfobacillus & This work \\
\hline 15 & $0.247 \pm 0.139$ & $0.643 \pm 0.058$ & $3.197 \pm 0.993$ & Sulfobacillus & This work \\
\hline 20 & $0.250 \pm 0.084$ & $0.654 \pm 0.067$ & $3.909 \pm 0.534$ & Sulfobacillus & This work \\
\hline 5.8 & 0.028 & 0.082 & $1.33 \times 10^{9}$ & A. brieleyi & {$[6]$} \\
\hline 20 & n.a. & 0.47 & n.a. & A. ferrooxidans & [6] \\
\hline 5 & 0.072 & 0.24 & $5.0 \times 10^{9}$ & L. ferriphilum & {$[14]$} \\
\hline 7.5 & n.a & 0.105 & n.a. & A. brieleyi & [6] \\
\hline
\end{tabular}

$\mathrm{pH}$ 1.8. The growth of Sulfolobus acidocaldarius also produced lower values of $\mu_{\max }\left(0.06 \mathrm{~h}^{-1}\right)$ and $K_{\mathrm{s}}\left(0.04 \mathrm{~g} \mathrm{~L}^{-1}\right)$ as observed by Vitaya et al. [12].

Table 1 presents the ferrous iron oxidation rate, the specific growth rate as well as the yield as a function of initial ferrous iron concentration. The change in biomass concentration can be related to yield $(Y)$ as follows [13]:

$\mu X=\frac{d X}{d t}=-Y \cdot \frac{d S}{d t} \quad$ or $\quad Y=\frac{X-X_{0}}{S_{0}-S}$

According to Table 1, the yield increases in the range of $2-5 \mathrm{~g} \mathrm{~L}^{-1}$ $\mathrm{Fe}(\mathrm{II})$, decreasing, however, for higher initial ferrous iron concentrations. The values determined in this work are in the same order of magnitude $\left(10^{9}\right.$ cells $\left.^{-1}\right)$ irrespective the initial ferrous iron concentrations. These results are one order of magnitude smaller than
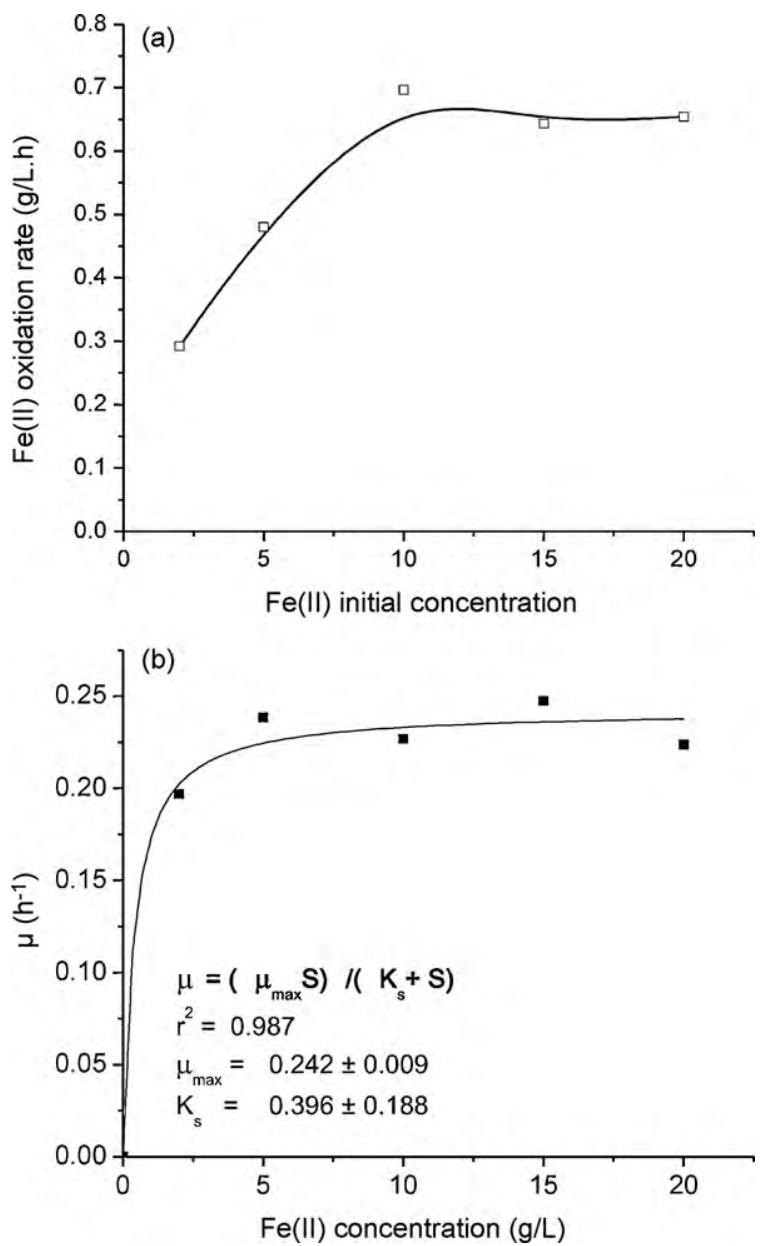

Fig. 3. Ferrous iron oxidation rate (a) and bacterial specific growth rate (b) determined during the growth of $S$. thermosulfidooxidans on $\mathrm{Fe}(\mathrm{II})$ as substrate. $50^{\circ} \mathrm{C}, 10 \%$ inoculum, $\mathrm{pH} 1.5$. those compiled by Nemati et al. [3] for A. ferrooxidans and similar to those observed by Nemati and Harrison [6] in experiments carried out with thermophilic microorganisms (A. brierleyi) as well as during the modeling of $L$. ferriphilium growth on Fe(II) [14].

The results show that although $S$. thermosulfidooxidans have $\mathrm{Fe}(\mathrm{II})$ oxidation rates similar to those determined for A. ferrooxidans, the bacterial growth rate is sensibly higher (Table 1) which reflects on a slightly smaller yield [15]. It has been reported higher bacterial growth rates in mixotrophic as compared to autotrophic conditions and it was proposed that obtaining carbon from organic sources is energetically more favorable than from carbon dioxide $[16,17]$. Although members of the genus Sulfobacillus can grow in autotrophic conditions, the largest growth rates are observed mixotrophically [18], unlike the obligate chemolithoautotroph $A$. ferrooxidans. During $S$. thermosulfidooxidans mixotrophic growth, the activity of the phosphoenolpyruvate (PEP) carboxylase enzyme is improved and is the highest among four different enzymes studied by Tsaplina et al. [19]. Conversely, the activity of the ribulose bisphosphate carboxylase (RuBPC) enzyme predominates during autotrophic growth and an increase on carbon dioxide content in the air fed to the system is needed for stable growth. This required (higher than atmospheric) $\mathrm{CO}_{2}$ content was proposed to be the reason why sulfobacilli is found in nature associated with microorganisms that show efficient $\mathrm{CO}_{2}$ fixation and can provide them with an organic carbon source [19].

Despite the higher growth rate shown by $S$. thermosulfidooxidans and due to similar Fe(II) oxidation kinetics as compared to $A$. ferrooxidans, the same behavior regarding the production of $\mathrm{Fe}(\mathrm{III})$ would be expected in either heap leaching or tank leaching operations. As the optimum growth temperature is higher, a faster sulfide leaching kinetics could be forecasted with positive implication on the process performance as already observed in selected systems $[20,21]$

\section{Conclusions}

A S. thermosulfidooxidans strain was able to grow in batch culture containing up to $20 \mathrm{~g} \mathrm{~L}^{-1} \mathrm{Fe}(\mathrm{II})$, with a maximum oxidation rate of $0.697 \mathrm{~g} \mathrm{~L}^{-1} \mathrm{~h}^{-1}$. The yield was a function of the initial ferrous iron concentration although in the same order of magnitude $\left(10^{9}\right.$ cells $\left.^{-1}\right)$. The Monod equation could successfully describe the growth kinetics and $\mu_{\max }$ and $K_{\mathrm{s}}$ values of $0.242 \mathrm{~h}^{-1}$ and $0.396 \mathrm{~g} \mathrm{~L}^{-1}$, respectively, were observed. The results show that the bacterium $S$. thermosulfidooxidans has growth kinetics faster than A. ferrooxidans, whereas Fe(II)-oxidation rates are similar for both microorganisms. Therefore, owing to the higher temperatures, faster sulfide leaching kinetics would be expected with potential benefits to process performance.

\section{Acknowledgements}

This work was supported by the Brazilian funding agencies FINEP, CNPq and FAPEMIG. The CAPES and CNPq scholarships to P.S Pina and V.A. Leão, respectively, are also gratefully acknowledged. 


\section{References}

[1] N.P. Marhual, N. Pradhan, R.N. Kar, L.B. Sukla, B.K. Mishra, Differentia bioleaching of copper by mesophilic and moderately thermophilic acidophilic consortium enriched from same copper mine water sample, Bioresour. Technol. 99 (2008) 8331-8336.

[2] T.V. Ojumu, J. Petersen, G.S. Hansford, The kinetics of ferrous-iron oxidation by Leptospirillum ferriphilum in continuous culture: the effect of temperature, Biochem. Eng. J. 46 (2009) 161-168.

[3] M. Nemati, S.T.L. Harrison, G.S. Hansford, C. Webb, Biological oxidation of ferrous sulphate by Thiobacillus ferrooxidans: a review on the kinetic aspects, Biochem. Eng. J. 1 (1998) 171-190.

[4] T.V. Ojumu, J. Petersen, G.E. Searby, G.S. Hansford, A review of rate equations proposed for microbial ferrous-iron oxidation with a view to application to heap bioleaching, Hydrometallurgy 83 (2006) 21-28.

[5] J.M. Gómez, I. Caro, D. Cantero, Kinetic equation for growth of Thiobacillus ferrooxidans in submerged culture over aqueous ferrous sulphate solutions, J. Biotechnol. 48 (1996) 147-152.

[6] M. Nemati, S.T.L. Harrison, A comparative study on thermophilic and mesophilic biooxidation of ferrous iron, Miner. Eng. 13 (2000) 19-24.

[7] P.M. Doran, Bioprocess Engineering Principles, Academic Press, San Diego, CA USA, 1995.

[8] P. Nurmi, B. Özkaya, A.H. Kaksonen, O.H. Tuovinen, J.A. Puhakka, Inhibition kinetics of iron oxidation by Leptospirillum ferriphilum in the presence of ferric, nickel and zinc ions, Hydrometallurgy 97 (2009) 137145.

[9] T.Y.I. Bogdanova, I.A. Tsaplina, T.F. Kondrat'eva, V.I. Duda, N.E. Suzina, V.S Melamud, T.Y.P. Tourova, G.I. Karavaiko, Sulfobacillus thermotolerans sp. nov. a thermotolerant, chemolithotrophic bacterium, Int. J. Syst. Evol. Microbiol. 56 (2006) 1039-1042.

[10] J.M. Gómez, D. Cantero, Modelling of ferrous sulphate oxidation by Thiobacillus ferrooxidans in discontinuous culture: influence of temperature, $\mathrm{pH}$ and agitation rate, J. Ferment. Bioeng. 86 (1998) 79-83.

[11] M.S. Liu, R.M.R. Branion, D.W. Duncan, The effects of ferrous iron, dissolved oxygen, and inert solids concentrations on the growth of Thiobacillus ferrooxidans, Can. J. Chem. Eng. 66 (1988) 445-451.
[12] V.B. Vitaya, J.-I. Koizumi, K. Toda, A kinetic assessment of substantial oxidation by Sulfolobus acidocaldarius in pyrite dissolution, J. Ferment. Bioeng. 77 (1994) 528-534.

[13] S. Molchanov, Y. Gendel, I. Ioslvich, O. Lahav, Improved experimental and computational methodology for determining the kinetic equation and the extant kinetic constants of $\mathrm{Fe}(\mathrm{II})$ oxidation by Acidithiobacillus ferrooxidans, Appl. Environ. Microbiol. 73 (2007) 1742-1752.

[14] K. Penev, D. Karamanev, Kinetics of ferrous iron oxidation by Leptospirillum ferriphilum at moderate to high total iron concentrations, in: E. Donati, M.R. Vieira, E.L. Tavani, A. Giaveno, T.L. Lavalle, P. Chiacchiarini (Eds.), IBS 09 - International Biohydrometallurgy Symposium, Trans Tech Publications, Bariloche, 2009, pp. 255-258.

[15] J.F. Braddock, H.V. Luong, E.J. Brown, Growth Kinetics of Thiobacillus ferrooxidans isolated from arsenic mine drainage, Appl. Environ. Microbiol 48 (1984) 48-55.

[16] L. Hallbeck, K. Pedersen, Autotrophic and mixotrophic growth of Gallionella ferruginea, J. Gen. Microbiol. 137 (1991) 2657-2661

[17] J.T. Pronk, R. Meulenberg, D.J.C. Van Den Berg, W. Batenburg-Van Der Vegte, P. Bos, J.G. Kuenen, Mixotrophic and autotrophic growth of Thiobacillus acidophilus on glucose and thiosulfate, Appl. Environ. Microbiol. 56 (1990) 3395-3401.

[18] W.J. Robertson, P.H.M. Kinnunen, J.J. Plumb, P.D. Franzmann, J.A. Puhakka, J.A.E. Gibson, P.D. Nichols, Moderately thermophilic iron oxidising bacteria isolated from a pyritic coal deposit showing spontaneous combustion, Miner. Eng. 15 (2002) 815-822.

[19] I. Tsaplina, E. Krasil'nikova, L. Zakharchuk, M. Egorova, T. Bogdanova, G. Karavaiko, Carbon metabolism in Sulfobacillus thermosulfidooxidans subsp. asporogenes, strain 41, Microbiology 69 (2000) 271-276.

[20] S.M. Mousavi, S. Yaghmaei, M. Vossoughi, A. Jafari, Efficiency of copper bioleaching of two mesophilic and thermophilic bacteria isolated from chalcopyrite concentrate of Kerman-Yazd regions in Iran, Sci. Iran 14 (2007) $180-184$.

[21] S.M. Mousavi, S. Yaghmaei, M. Vossoughi, A. Jafari, R. Roostaazad, Zinc extraction from Iranian low-grade complex zinc-lead ore by two native microorganisms: Acidithiobacillus ferrooxidans and Sulfobacillus, Int. J. Miner. Process. 80 (2006) 238-243. 